UDC 622.7:622.341(470.325)

T. N. GZOGYAN ${ }^{1}$, Head of laboratory, mehanobr1@yandex.ru

S. R. GZOGYAN ${ }^{1}$, Senior Researcher

E. V. GRISHKINA ${ }^{1}$, Junior Researcher

${ }^{1}$ Belgorod National University, Belgorod, Russia

\title{
DEEP CONCENTRATION OF HIGH-GRADE IRON ORE IN THE BELGOROD REGION OF THE KURSK MAGNETIC ANOMALY
}

\section{Introduction}

To compete successfully on the world market of iron ore products, the domestic industry demands high-quality feedstock suitable for direct metallization deposition. The latter means that the feedstock is to be of higher metallurgical value which is governed by contents of useful components, impurities and slag-forming oxides [1-3]. A promising and secure source of raw materials for the iron industry of Russia is deep-seated deposits of naturally occurring rich ore in the Belgorod iron ore province of the Kursk Magnetic Anomaly [4]. Alongside with colossal reserves and high quality, the advantage of these ore bodies is very comfortable combination of geographical, natural and economic conditions $[4,5]$.

At different times (1992-2000) deep concentration of rich iron ores produced in the mentioned area (including the Yakovlevo field) was often approached using various methods. According to [6-8] the rich local deposits are composed of uniform geological and mineralogical types that belong to diverse mineral kinds depending on the presence and quantitative ratio of oregenetical and secondary associated minerals.

\section{Technological study}

The technological study into deep concentration of rich iron ore was carried out using large-volume samples of mineralogical varieties from the Yakovlevo deposit. This ore has similar composition and properties as rich ore from the other deposits in the region $[3,4]$.

The study objects were such mineralogical varieties as: micaceous iron oxide-martite, chloritized, semiloose, $-100 \mathrm{~mm}$ in size (Ya-1); martite-hydrohematite, loose, $-100 \mathrm{~mm}$ in size (Ya-2); micaceous iron oxidemartite, loose, with chlorite, $-350 \mathrm{~mm}$ in size (Ya-3); martite-hydrohematite-hydrogoethite, loose, clay-like (pigmented), $-100 \mathrm{~mm}$ in size (Ya-4); martite with micaceous iron oxide, low-chloritized, loose, $-350 \mathrm{~mm}$ in size (Ya-5); and micaceous iron oxide-martite, hard-rock, $-350 \mathrm{~mm}$ in size (Ya-6). Total chemical compositions of bulk samples are described in Table 1.
Table 1. Total chemical composition of technological samples

\begin{tabular}{|c|c|c|c|c|c|c|}
\hline \multirow{2}{*}{$\begin{array}{c}\text { Oxides and } \\
\text { components }\end{array}$} & \multicolumn{5}{|c|}{ Mass percent per sample } \\
\cline { 2 - 7 } & Ya-1 & Ya-2 & Ya-3 & Ya-4 & Ya-5 & Ya-6 \\
\hline $\mathrm{Fe}_{\text {total }}$ & 66.2 & 62.2 & 67.9 & 53.3 & 68.3 & 58.8 \\
\hline $\mathrm{FeO}$ & 2.92 & 5.1 & 3.5 & 5.1 & 3.4 & 5.9 \\
\hline $\mathrm{Fe}_{2} \mathrm{O}_{3}$ & 91.5 & 83.3 & 93.2 & 70.55 & 93.8 & 77.4 \\
\hline $\mathrm{SiO}_{2}$ & 2.5 & 3.7 & 1.2 & 6.1 & 1.0 & 9.5 \\
\hline $\mathrm{Al}_{2} \mathrm{O}_{3}$ & 1.15 & 1.75 & 0.78 & 2.7 & 0.55 & 2.7 \\
\hline $\mathrm{CaO}$ & 0.3 & 0.7 & 0.3 & 1.5 & 0.2 & 0.55 \\
\hline $\mathrm{MgO}$ & 0.3 & 0.3 & 0.14 & 0.64 & 0.2 & 0.3 \\
\hline $\mathrm{TiO}_{2}$ & 0.04 & 0.11 & 0.01 & 0.15 & 0.02 & 0.02 \\
\hline $\mathrm{MnO}^{\mathrm{n} O}$ & 0.04 & 0.08 & 0.06 & 0.15 & 0.04 & 0.07 \\
\hline $\mathrm{S}$ & 0.06 & 0.025 & 0.04 & 0.033 & 0.02 & 0.11 \\
\hline $\mathrm{P}_{2} \mathrm{O}_{5}$ & 0.04 & 0.05 & 0.06 & 0.06 & 0.04 & 0.05 \\
\hline calcination & 1.22 & 4.83 & 0.55 & 13.0 & 0.41 & 2.84 \\
\hline $\mathrm{K}_{2} \mathrm{O}$ & 0.06 & 0.08 & 0.06 & 0.07 & 0.04 & 0.08 \\
\hline $\mathrm{Na}_{2} \mathrm{O}$ & 0.11 & 0.1 & 0.12 & 0.13 & 0.05 & 0.12 \\
\hline Loss in & & & & & \\
\hline
\end{tabular}


Table 2. Characteristics of fraction $-1 \mathrm{~mm}$ of loose and semi-loose varieties

\begin{tabular}{|c|c|c|c|c|c|c|c|}
\hline \multirow{2}{*}{$\begin{array}{c}\text { Yield of size (from }-1 \mathrm{~mm} \text { ) } \\
\text { per sample, } \%\end{array}$} & \multicolumn{7}{|c|}{ Mass fraction per size $(\mathrm{mm}), \%$} \\
\hline & +0.56 & $-0.56+0.28$ & $-0.28+0.16$ & $-0.16+0.071$ & $-0.071+0.045$ & -0.045 & Total \\
\hline \multicolumn{8}{|c|}{$Y a-1$} \\
\hline $\begin{array}{l}\text { Yield } \\
\mathrm{Fe}_{\text {total }} \\
\mathrm{SiO}_{2} \\
\mathrm{Al}_{2} \mathrm{O}_{3}\end{array}$ & $\begin{array}{c}1.0 \\
67.3 \\
2.15 \\
0.45\end{array}$ & $\begin{array}{c}1.9 \\
67.2 \\
2.1 \\
0.45\end{array}$ & $\begin{array}{c}0.8 \\
66.7 \\
2.5 \\
0.46\end{array}$ & $\begin{array}{c}1.2 \\
66.61 \\
2.0 \\
0.54\end{array}$ & $\begin{array}{c}1.1 \\
67.75 \\
1.27 \\
0.6\end{array}$ & $\begin{array}{c}9.4 \\
68.12 \\
1.0 \\
0.66\end{array}$ & $\begin{array}{c}15.4 \\
67.37 \\
1.45 \\
0.62\end{array}$ \\
\hline \multicolumn{8}{|c|}{ Ya-2 } \\
\hline $\begin{array}{l}\text { Yield } \\
\mathrm{Fe}_{\text {total }} \\
\mathrm{SiO}_{2} \\
\mathrm{Al}_{2} \mathrm{O}_{3}\end{array}$ & $\begin{array}{c}2.4 \\
61.5 \\
4.75 \\
2.2\end{array}$ & $\begin{array}{c}3.9 \\
62.2 \\
4.0 \\
2.0\end{array}$ & $\begin{array}{c}4.1 \\
62.9 \\
2.0 \\
1.35\end{array}$ & $\begin{array}{c}13.0 \\
66.1 \\
1.2 \\
1.0\end{array}$ & $\begin{array}{c}6.0 \\
66.6 \\
1.5 \\
1.2\end{array}$ & $\begin{array}{c}9,0 \\
60.0 \\
2.35 \\
1.25\end{array}$ & $\begin{array}{c}38.4 \\
63.72 \\
2.10 \\
1.30\end{array}$ \\
\hline \multicolumn{8}{|c|}{ Ya-3 } \\
\hline $\begin{array}{l}\text { Yield } \\
\mathrm{Fe}_{\text {total }} \\
\mathrm{SiO}_{2} \\
\mathrm{Al}_{2} \mathrm{O}_{3}\end{array}$ & $\begin{array}{c}3.1 \\
67.0 \\
0.7 \\
0.6 \\
\end{array}$ & $\begin{array}{c}4.5 \\
68.7 \\
0.7 \\
0.55 \\
\end{array}$ & $\begin{array}{c}2.4 \\
68.7 \\
0.5 \\
0.45\end{array}$ & $\begin{array}{c}6.3 \\
69.4 \\
0.4 \\
0.45 \\
\end{array}$ & $\begin{array}{c}4.7 \\
69.6 \\
0.35 \\
0.5 \\
\end{array}$ & $\begin{array}{c}7.9 \\
67.2 \\
0.48 \\
0.6 \\
\end{array}$ & $\begin{array}{c}28.9 \\
68.41 \\
0.50 \\
0.53 \\
\end{array}$ \\
\hline \multicolumn{8}{|c|}{ Ya-4 } \\
\hline $\begin{array}{l}\text { Yield } \\
\mathrm{Fe}_{\text {total }} \\
\mathrm{SiO}_{2} \\
\mathrm{Al}_{2} \mathrm{O}_{3}\end{array}$ & $\begin{array}{c}1.6 \\
62.6 \\
6.5 \\
3.3 \\
\end{array}$ & $\begin{array}{c}2.4 \\
53.0 \\
6.15 \\
3.15 \\
\end{array}$ & $\begin{array}{c}1.1 \\
54.1 \\
5.9 \\
3.0\end{array}$ & $\begin{array}{c}1.8 \\
56.2 \\
5.6 \\
2.7\end{array}$ & $\begin{array}{c}1.1 \\
57.5 \\
4.6 \\
2.3 \\
\end{array}$ & $\begin{array}{c}6.9 \\
58.1 \\
3.9 \\
1.8 \\
\end{array}$ & $\begin{array}{c}14.9 \\
57.19 \\
4.95 \\
2.41\end{array}$ \\
\hline \multicolumn{8}{|c|}{ Ya-5 } \\
\hline $\begin{array}{l}\text { Yield } \\
\mathrm{Fe}_{\text {total }} \\
\mathrm{SiO}_{2} \\
\mathrm{Al}_{2} \mathrm{O}_{3}\end{array}$ & $\begin{array}{c}1.8 \\
68.7 \\
0.95 \\
0.5\end{array}$ & $\begin{array}{c}6.1 \\
68.6 \\
0.9 \\
0.5\end{array}$ & $\begin{array}{c}4.7 \\
68.5 \\
1.1 \\
0.6\end{array}$ & $\begin{array}{c}10.5 \\
68.7 \\
0.9 \\
0.5\end{array}$ & $\begin{array}{c}6.2 \\
68.9 \\
0.7 \\
0.4\end{array}$ & $\begin{array}{c}32.9 \\
68.0 \\
0.75 \\
0.5\end{array}$ & $\begin{array}{c}62.2 \\
68.32 \\
0.82 \\
0.50\end{array}$ \\
\hline
\end{tabular}
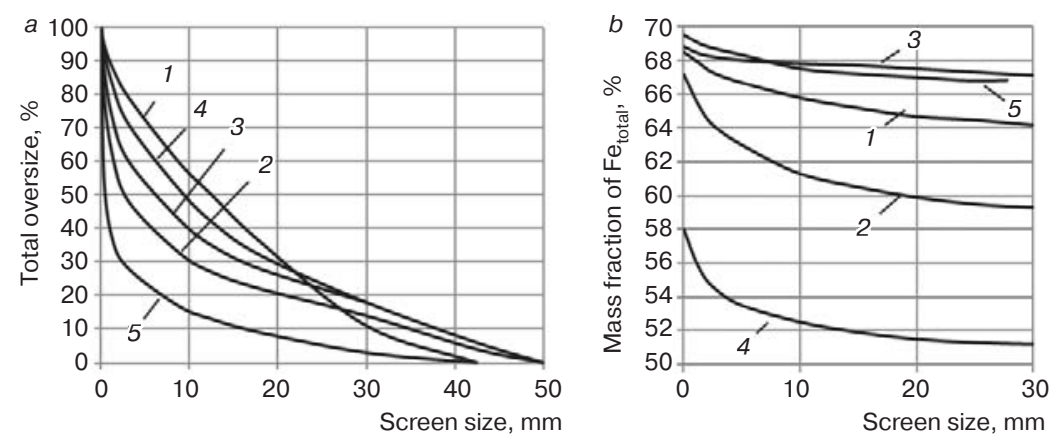

Fig. 1. Grain size composition (a) and size distribution of $\mathrm{Fe}_{\text {total }}(\mathrm{b})$ in technological samples:

1 - micaceous iron oxide-martite, chloritized, semi-loose Ya-1;

2 - martite-hydrohematiter, loose Ya-2; 3 - micaceous iron oxidemartite, loose, with chlorite Ya-3; 4 - martite-hydrohematitehydrogoethite, loose Ya-4; 5 - martite with micaceous iron oxide, low-chloritized, loose Ya-5

Before primary estimation, for each mineralogical variety, a treatment scheme and a study model were developed $[9,10]$. Each mineralogical variety was re-ground down to the size of $-50 \mathrm{~mm}$. The distribution of the size grades and chemical components $\left(\mathrm{Fe}_{\text {total }}, \mathrm{SiO}_{2}\right.$ and $\left.\mathrm{Al}_{2} \mathrm{O}_{3}\right)$ is demonstrated in Figs. 1 and 2. The lowest size limit for similar ore is $8 \mathrm{~mm}$; this particle size ensures optimal processing at the moisture content not higher than $9 \%$.

The yield of size $-8 \mathrm{~mm}$ ranged from 38.5 to $81.9 \%$ in the loose and semi-loose varieties, respectively, and from 15.6 to $65.5 \%$ in the other varieties. The size distribution of the chemical components $\left(\mathrm{Fe}_{\text {total }}, \mathrm{SiO}_{2}\right.$ and $\left.\mathrm{Al}_{2} \mathrm{O}_{3}\right)$ has a
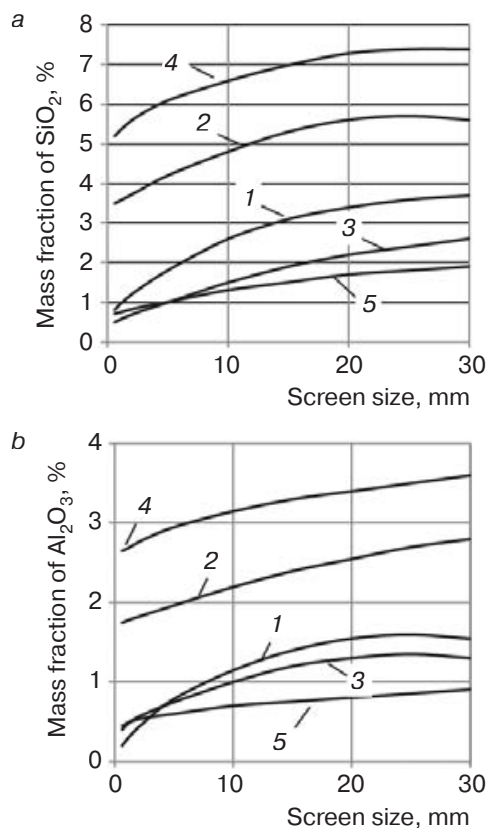

Fig. 2. Distribution of $\mathrm{SiO}_{2}(a)$ and $\mathrm{Al}_{2} \mathrm{O}_{3}$ (b) per size grades in technological samples (the curves are explained in Fig. 1

distinct trend of increasing $\mathrm{Fe}_{\text {total }}$ and decreasing $\mathrm{SiO}_{2}$ and $\mathrm{Al}_{2} \mathrm{O}_{3}$ in the line from the large to small classes $(-1 \mathrm{~mm})$ (see Figs. 1 and 2). All samples contained high amount of the size $-1 \mathrm{~mm}$; for this reason, it was decided to analyze distribution of the main chemical components in the size less than $1 \mathrm{~mm}$. From the results, deep desliming or 
Table 3. Averaged characteristic of technological samples after classification by size $8 \mathrm{~mm}$

\begin{tabular}{|c|c|c|c|c|c|}
\hline \multirow{2}{*}{ Sample } & \multicolumn{2}{|c|}{ Classification product } & \multicolumn{3}{|c|}{ Mass percent per size } \\
\cline { 2 - 6 } & Size, mm & Yield, \% & $\mathrm{Fe}_{\text {total }}$ & $\mathrm{SiO}_{2}$ & $\mathrm{Al}_{2} \mathrm{O}_{3}$ \\
\hline \multirow{3}{*}{ Ya-1 } & +8 & 61.5 & 65.45 & 3.13 & 1.36 \\
& $-8+0$ & 38.5 & 67.65 & 1.46 & 0.71 \\
& Initial & 100.0 & 66.30 & 2.61 & 1.11 \\
\hline \multirow{3}{*}{ Ya-2 } & +8 & 34.5 & 59.57 & 4.17 & 2.29 \\
& $-8+0$ & 65.5 & 63.66 & 3.52 & 1.48 \\
& Initial & 100.0 & 62.25 & 3.74 & 1.76 \\
\hline \multirow{3}{*}{ Ya-3 } & +8 & 44.3 & 67.49 & 1.84 & 1.05 \\
& $-8+0$ & 55.7 & 68.25 & 0.78 & 0.62 \\
& Initial & 100.0 & 67.91 & 1.25 & 0.81 \\
\hline \multirow{3}{*}{ Ya-4 } & +8 & 53.7 & 51.71 & 6.42 & 2.74 \\
& $-8+0$ & 46.3 & 55.19 & 6.01 & 2.49 \\
& Initial & 100.0 & 53.32 & 6.23 & 2.62 \\
\hline \multirow{3}{*}{ Ya-5 } & $+8,0$ & 18.1 & 67.42 & 1.52 & 0.7 \\
& $-8,0+0$ & 81.9 & 68.47 & 0.85 & 0.51 \\
& Initial & 100.0 & 68.28 & 0.97 & 0.54 \\
\hline \multirow{3}{*}{ Ya-6 } & +8 & 84.4 & 58.42 & 10.38 & 2.89 \\
& $-8+0$ & 15.6 & 60.45 & 4.97 & 1.52 \\
& Initial & 100.0 & 58.74 & 9.54 & 2.68 \\
\hline
\end{tabular}

hydraulic classification has no noticeable effect, while wet separation processes lead to high losses of marketable products as well as to difficult dewatering and drying (Table 2).

The authors think the most efficient method of separating rich particles from loose and semi-loose ore types is screen sizing. The experimental results proved feasibility of producing high-quality iron ore concentrate from loose and semi-loose micaceous iron oxide-magnetite ore for direct reduction (Table $\mathbf{3}$ ).

Another simple alternative of rich loose ore separation from bulk production flow to a marketable product can be selective grinding and screening. The earlier research $[6,8]$ found an evident correlation between the size (adequate to the strength) and the quality of ore both within the same and different mineralogical varieties (less strong components featured higher quality). At the same time, loose and semi-loose ores contain weakly cemented rich (in terms of $\mathrm{Fe}_{\text {total }}$ ) varieties which remain in oversize product in screening and reduce the quality ore yield. In this respect, it is required to disintegrate these varieties while more compact (hard and semi-hard rock) should remain intact. Disintegration in the selected optimal mode (rotor speed $15 \mathrm{~m} / \mathrm{s}$ ) was carried out on disintegrator DESI-16C (Fig. 3).

The analysis of the results shows an increased mass fraction of $\mathrm{Fe}_{\text {total }}$ in the size $-8 \mathrm{~mm}$ and a decreased fraction of total iron in the size $+8 \mathrm{~mm}$ (the difference is from 0.76 to $4.09 \%$ ). The mass fraction of $\mathrm{SiO}_{2}$ in these sizes is also different (changes from 0.41 to $5.41 \%$ ) (Table 3 ). Moreover, in case of the smaller mass fraction in the feed of the disintegrator, the difference in the mass fraction of $\mathrm{Fe}_{\text {total }}$ between these sizes is higher.

Thus, selective grinding and screening of the fraction $+8 \mathrm{~mm}$ after primary screening of loose and semi-loose mineralogical varieties produced $15-26 \%$ of a product suitable for metallization deposition, with $\mathrm{Fe}_{\text {total }}$ up to 67.5

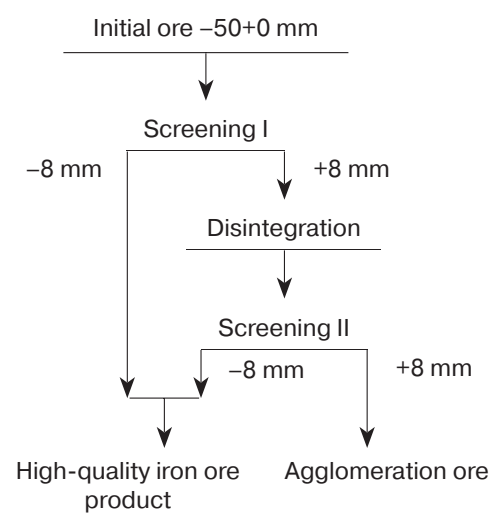

Fig. 3. Selective grinding and screening circuit for loose and semi-loose ore

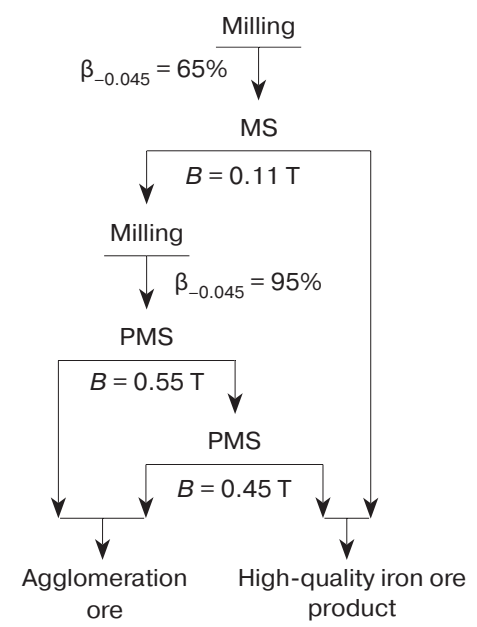

Fig. 4. Basic diagram of magnetic treatment of size $-8 \mathrm{~mm}$

and $\mathrm{SiO}_{2}$ to $1.84 \%$. The mass fractions of sulfur and phosphorus were $0.01-0.015 \%$, and up to $0.06 \%$, respectively, while the ratio of slag-forming basic acid oxides was 0.2 $0.25 \%$. These imply that the product satisfies the metallization deposition standards.

In the meanwhile, the Yakovlevo deposit, as the other local ore bodies, contains low-grade ore (Ya-6)-carbonatized varieties with mass fractions of $\mathrm{Fe}_{\text {total }}=55 \div 60 \%$ and $\mathrm{SiO}_{2}=8 \div 10 \%$. Additional treatment of such varieties (grinding+screening) can produce agglomerated or lump blast-furnace ore. The low-grade varieties also include hydrohematite-hydrogoethite (pigmentated) ore types which are suitable for selected extraction and re-processing by special technology. The pilot experiments with sluicing extracted iron oxide slimes (to 50\%) and compact martite varieties $\left(\mathrm{Fe}_{\text {total }}=55 \div 60 \%\right)$ convenient for agglomeration. The iron oxide slimes (after thickening, roasting, drying and milling) are the feedstock for the pink-and-varnish industry (iron oxide pigments) [11].

In this manner, as the research has shown, production of iron ore material for metallization deposition can use a simple circuit with screening and selective screening.

The special-purpose production needs deep 
Table 4. Averaged balance sheet data on processing of micaceous iron oxide-martite variety by different methods, \%

\begin{tabular}{|c|c|c|c|c|c|c|c|c|c|}
\hline \multirow{3}{*}{ Processing method } & \multicolumn{9}{|c|}{ Technological parameters of products, \% } \\
\hline & \multicolumn{3}{|c|}{ Initial } & \multicolumn{3}{|c|}{ High-quality } & \multicolumn{3}{|c|}{ Waste (tailings) } \\
\hline & Yield & $\mathrm{Fe}_{\text {total }} / \mathrm{SiO}_{2}$ & $\begin{array}{l}\text { Recovery } \\
\text { of Fe } e_{\text {total }}\end{array}$ & Yield & $\mathrm{Fe}_{\text {total }} / \mathrm{SiO}_{2}$ & $\begin{array}{l}\text { Recovery } \\
\text { of } \mathrm{Fe}_{\text {total }}\end{array}$ & Yield & $\mathrm{Fe}_{\text {total }} / \mathrm{SiO}_{2}$ & $\begin{array}{l}\text { Recovery } \\
\text { of Fe } \mathrm{Fe}_{\text {total }}\end{array}$ \\
\hline $\begin{array}{l}\text { High-level magnetic separation } \\
\text { (size }-8 \mathrm{~mm} \text {, semi-loose) }\end{array}$ & 38.5 & $67.65 / 1.46$ & 39.28 & 26.0 & $69.0 / 0.32$ & 27.06 & 12.5 & $64.82 / 4.82$ & 12.22 \\
\hline $\begin{array}{l}\text { Gravity separation (size }-8 \mathrm{~mm} \text {, } \\
\text { semi-loose) }\end{array}$ & 38.5 & $67.65 / 1.46$ & 39.28 & 25.6 & $68.51 / 0.15$ & 26.45 & 12.9 & $65.94 / 4.06$ & 12.83 \\
\hline Flotation (loose) & 100.0 & $67.91 / 1.25$ & 100.0 & 95.0 & $68.21 / 1.01$ & 95.42 & 5.0 & $62.2 / 4.05$ & 4.58 \\
\hline
\end{tabular}

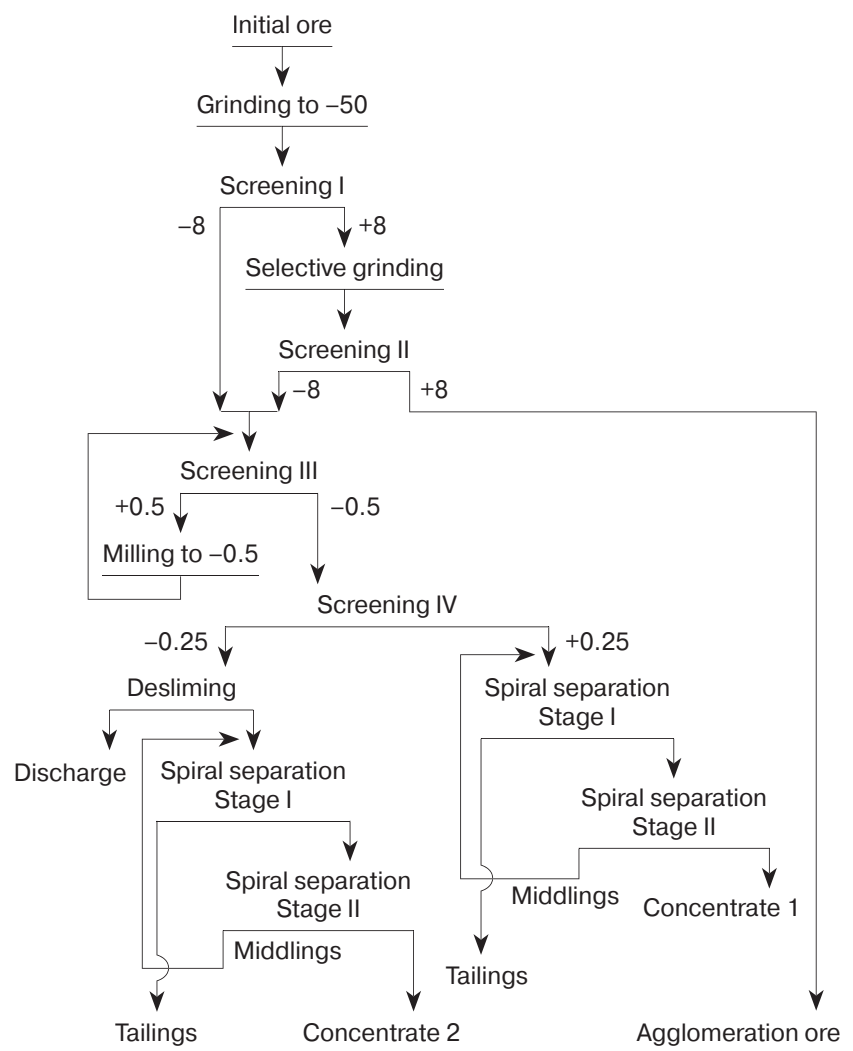

Fig. 5. Basic diagram of gravity separation

concentration by different methods. Internationally, hematite ore is the most widely treated by polygradient magnetic separation (PMS) [12]. The magnetic processing experimentation used the circuit in Fig. 4 and the milled size $-8 \mathrm{~mm}$ (to $65-70 \%$ content $-0.045 \mathrm{~mm}$ ). The first stage of magnetic separation (MS) was carried out on lab magnetic separator EBM-32/20 at the field density $B$ of 0.11 $T$ to prevent PMS blockage in extraction of magnetite and relics from ore. PMS was implemented on analyzer R-40 composed of an electromagnetic system and a nonmagnetic matrix filled with checker plates made of magnetically soft material. The MS tailings milled up to the $90 \%$ content of the size $-0.045 \mathrm{~mm}$ were subjected to PMS at $B=0.5 \mathrm{~T}$ in the gap between the plates. The effect of the magnetic field density on the separation efficiency was pre-examined. It is found that when the field density is changed from 0.3 to $0.7 \mathrm{~T}$, the yield of the magnetic product reduces from 98.8 to $67.8 \%$ while the mass fractions of $\mathrm{Fe}_{\text {total }}$ in the

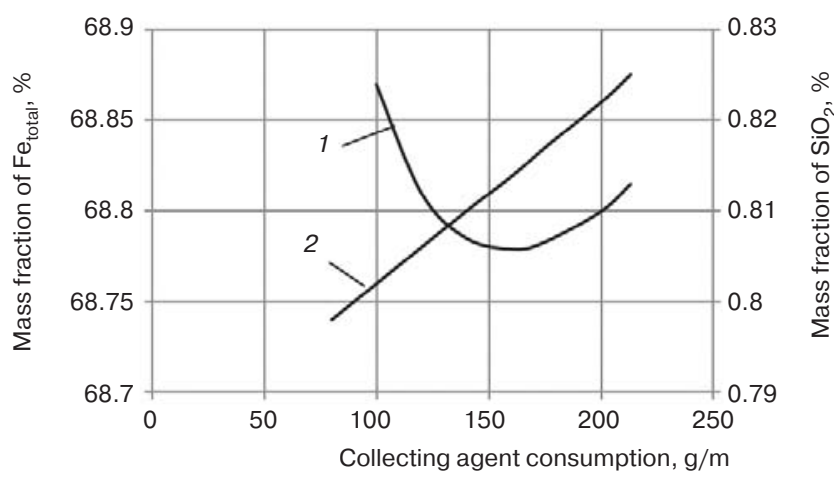

Fig. 6. Dependence of mass fractions of $\mathrm{SiO}_{2}(1)$ and $\mathrm{Fe}_{\text {total }}(2)$ in flotation concentrate on consumption of collecting agent

concentrates differ inconsiderably: $\mathrm{Fe}_{\text {total }}=68.03 \%$ and $\mathrm{SiO}_{2}=0.93 \%$ at $B=0.3 \mathrm{~T}$ whereas $\mathrm{Fe}_{\text {total }}=67.85 \%$ and $\mathrm{SiO}_{2}=1.23 \%$ at $B=0.7 \mathrm{~T}$.

The further studies assumed the field density $B=0.5 \mathrm{~T}$. When treated by MS at $B=0.11 \mathrm{~T}$, the variation ranges were wider: yield of the concentrate - from 0 to $33.1 \%$, mass fraction of $\mathrm{Fe}_{\text {total }}$ in the concentrate - from 68.5 to $69.78 \%$, and $\mathrm{SiO}_{2}-$ from 0.34 to $0.59 \%$. The PMS concentrate was scavenged on the same analyzer at $B=0.45 \mathrm{~T}$. The total concentrate yield varied from 34.2 to $71.8 \%$, mass fraction of $\mathrm{Fe}_{\text {total }}$ - from 67.17 to $69.13 \%$, and $\mathrm{SiO}_{2}$ - from 1.51 to $0.62 \%$. The mass fraction of $\mathrm{Fe}_{\text {total }}$ in tailings was 57.21 to $67.02 \%$, and the latter was a suitable product to be used as a feedstock for agglomeration.

On individual basis, test treatment of the size $-8 \mathrm{~mm}$ extracted from micaceous iron oxide-martite (Ya-1) was carried out. The test deep concentration of the product gave the total concentrate with $\mathrm{Fe}_{\text {total }}=69.0 \%$ and $\mathrm{SiO}_{2}=$ $=0.32 \%$ at the yield of $62.3 \%$ (from the size $-8 \mathrm{~mm}$ ). Joint tailings $\left(\mathrm{Fe}_{\text {total }}=65 \%\right.$ and $\left.\mathrm{SiO}_{2}=4.82 \%\right)$ are dewatered and blended with agglomeration ore. Thus, the resultant highquality product meets requirements of the powder metallurgy, battery production, etc.

Different weights of metallic and nonmetallic minerals made grounds for undertaking test separation by gravity. The gravity concentration was carried out as separation in spiral sluices manufactured by SPIRIT NPF (Fig. 5). Selective grinding and screening of an initial sample separated the size $-8 \mathrm{~mm}$ from it; the size $+8 \mathrm{~mm}$ was the final product (agglomeration ore). Wet screening of the size $-8 \mathrm{~mm}$ 
extracted the size $-0.5 \mathrm{~mm}$ (size $+0.5 \mathrm{~mm}$ was remilled down to the size $-0.5 \mathrm{~m}$ and mixed with the size $-0.5 \mathrm{~mm}$ produced by wet screening). Then, the size $-0.5 \mathrm{~mm}$ was separated with regard to the size $0.25 \mathrm{~mm}$. The fraction $-0.25 \mathrm{~mm}$ was subjected to desliming, and the sands were treated on the spiral separator at two stages with production of concentrate and tailings.

The fraction $-0.5+0.25 \mathrm{~mm}$ was processed by the same scheme. From the analysis of the results, in the gravity dressing of the size $-0.25 \mathrm{~mm}$, after desliming, the concentrate enjoys the increase in $\mathrm{Fe}_{\text {total }}$ by $0.86 \%$ and the decrease in the mass fraction of $\mathrm{SiO}_{2}$ by $0.04-0.29 \%$. The less increment in $\mathrm{Fe}_{\text {total }}$ in concentrate is observed after processing of the size $-0.5+0.25 \mathrm{~mm}$ (not higher than $0.08-0.45 \%)$.

The mineralogical optic analysis of the gravity concentrates after treatment of the sizes $-0.5+0.25$ and $-0.25 \mathrm{~mm}$ finds that the concentrates are impure with high-grade and low-grade aggregates (martite- and hematite-chlorite) of metallic and nonmetallic (chlorite) minerals. Based on the aforesaid, the gravity separation is inefficient with fine sizes of high-grade iron ore of various mineralogical varieties, and is not recommended to be used as the basic procedure.

Flotation as the main method of iron ore dressing involves some difficulties and, first and foremost, wastewater purification. Re-treatment of PMS concentrate was carried out by reverse cation flotation. The collecting agent in all tests was cation collector PA-14 (Tomah, USA); the modifying agent was the solution $\mathrm{NaOH}(\mathrm{pH}$ was varied from 8-8.5 to 10-10.5); the depressing agent for iron oxides was modified corn flour. The experiments showed no essential effect of $\mathrm{pH}$ variation in the medium on the technological parameters of separation.

It is found that consumption of the cation collector both slightly increases $\mathrm{Fe}_{\text {total }}$ (from 68.76 to $68.85 \%$ ) and decreases $\mathrm{SiO}_{2}$ (from 0.82 to $0.80 \%$ ) in the middlings (concentrate). Such low efficiency of flotation of the magnetic product is connected with the presence of chlorite which is tightly intergrown with metallic minerals (hematite and martite) and inextractable to froth (tailings). The influence of the reagent mode on the separation performance is illustrated in Fig. 6 (sample Ya-3). The analysis of the magnetic product flotation shows that the mass fraction of $\mathrm{Fe}_{\text {total }}$ rises merely by $0.1-0.33 \%$ while $\mathrm{SiO}_{2}$ reduces by $0.05-0.11 \%$ in all mineralogical varieties of high-grade ore.

Low efficiency of flotation in re-processing of concentrates impedes recommending this method for high-grade iron ore deposits in the region.

\section{Conclusion}

The primary investigation has shown that it is possible to obtain high-quality iron product from naturally occurring high-grade iron ore using a simple technology (Table 4). Moreover, re-processing of rich iron ore can be wasteless, which significantly mitigates the environmental impact in the region [5. 8]. Also, it should be emphasized that wet separation processes inevitably result in considerable loss of marketable products and bring difficulties connected with dewatering and drying.

References

1. Pomelnikov I. I. State and prospects of iron-ore industry development with stable decrease of global iron ore prices. Gornyi Zhurnal. 2015. No. 7. pp. 78-87. DOI: 10.17580/ gzh.2015.07.11

2. Yushina T. I., Petrov I. M., Avdeev G. I., Valavin V. S. Analysis of state-of-the-art in iron ore mining and processing in Russian Federation. Gornyi Zhurnal. 2015. No. 1. pp. 41-47. DOI: 10.17580/gzh.2015.01.08

3. Kuskov V. B., Sishchuk Yu. M. Improvement of beneficiation technologies for iron ore of various type and material constitution. Gornyi Zhurnal. 2016. No. 2. pp. 70-73. DOI: 10.17580/ gzh.2016.02.14

4. Dunay E. I., Belykh V. I., Pogoreltsev I. A. Industrial capacity of mineral and raw material resources in the Belgorod Region. Gornyi Zhurnal. 2014. No. 8. pp. 37-40.

5. Orlov V. P., Verigin M. I., Golivkin N. I. (Eds.). Iron ore base of Russia. Moscow : Geoinformmark, 1998. 842 p.

6. Gzogyan T. N., Gzogyan S. R. Material composition of rich iron deposits of KMA. Nauchnye vedomosti BelGU. 2018. Vol. 42 , No. 2. pp. 131-141.

7. Gzogyan T. N., Gzogyan S. R., Grishkina E. V. Rich iron ore in the Belgorod Region of the Kursk Magnetic Anomaly as potential resource for metallization. Eurasian Mining. 2019. No. 1. pp. 3-7. DOI: 10.17580/em.2019.01.01

8. Gzogyan T. N., Gzogyan S. R., Grishkina E. V. Finding deep concentration techniques for rich iron ore of the Kursk Magnetic Anomaly. Journal of Mining Science. 2019. No. 2.

9. Bhadani K., Asbjörnsson G., Hulthén T., Evertsson M. Application of multi-disciplinary optimization architectures in minera processing simulations. Minerals Engineering. 2018. Vol. 128 , pp. 27-35.

10. Wills B. A., Finch J. A. Wills' Mineral Processing Technology. Butterworth-Heinemann, 2015. $512 \mathrm{p}$.

11. Kuskov V. B., Kuskova Ya. V. Development of technology for preparing iron oxide pigments. Metallurgist. 2010. Vol. 54 No. 3-4. pp. 192-194.

12. Oliazadeh M., Vazirizadeh A. Removing impurities from iron ores: methods and industrial cases. XXVIII IMPC, Quebec, September 11-15, 2016. Paper 711. pp. 1-13. 